\title{
ESTIMATING PARASITOID IMMATURE MORTALITY BY COMPARING OVIPOSITION AND PUPAL DEVELOPMENT OF Trichogramma galloi ZUCCHI AND T. pretiosum RILEY ON NATURAL AND FACTITIOUS HOSTS
}

\author{
CÔNSOLI, F. L., ${ }^{1}$ PARRA, J. R. P. ${ }^{1}$ and VINSON, S. B. ${ }^{2}$ \\ ${ }^{1}$ Departamento de Entomologia, ESALQ/USP, C.P. 9, CEP 13418-900, Piracicaba, SP, Brazil \\ ${ }^{2}$ Department of Entomology, Texas A\&M University, College Station, TX 77843-2475, USA \\ Correspondence to: Fernando Luís Cônsoli, Texas A\&M University, Entomology Research Laboratory, College \\ Station, Texas 77843-2475, USA, e-mail: flc6940@pop.tamu.edu \\ Received February 1, 1999 - Accepted May 26, 1999 - Distributed August 31, 2000
}

(With 1 figure)

\begin{abstract}
Mortality during the immature development of T. galloi and T. pretiosum was estimated on UV-killed and live eggs of a factitious and a natural host, respectively. A staining technique was used to determine the actual parasitization of UV-treated eggs and was compared with the number of parasitoids that emerged per host egg (detectable parasitization). Effects of temperature as a factor of mortality during the immature development of both parasitoids on the factitious host was also assessed. The actual and detectable parasitization of live hosts was measured by recording both the parasitization behavior and the number of eggs where a parasitoid developed successfully. Our data show that mortality during immature development of both parasitoids may occur in live eggs of the natural host. No such mortality was observed when parasitoids developed on UV-killed eggs of the factitious host. Possible causes of parasitoid immature mortality and the effects of using UV-treated eggs of factitious hosts in estimating the parasitism capacity of Trichogramma in field conditions are discussed.
\end{abstract}

Key words: biological control, host exploitation, host/parasitoid interaction, host suitability, immature mortality, parasitoid fitness, parasitization rate.

\section{RESUMO \\ Estimating Parasitoid Immature Mortality by Comparing Oviposition and Pupal Development of Trichogramma galloi ZUCCHI and T. pretiosum RILEY on Natural and Factitious Hosts}

A mortalidade durante o desenvolvimento das formas imaturas de Trichogramma galloi e T. pretiosum foi estimada em ovos do hospedeiro alternativo, invibializados em lâmpada germicida, e do hospedeiro natural (não-tratados). Uma técnica de coloração foi utilizada para determinar o real parasitismo (número de ovos do parasitóide colocados por ovo do hospedeiro) do hospedeiro alternativo, e o valor determinado foi comparado ao número de adultos emergidos por ovo hospedeiro (parasitismo mensurável). O efeito da temperatura como fator de mortalidade para os estágios iniciais do desenvolvimento de ambas as espécies de parasitóide também foi avaliado. O parasitismo real e o mensurável de ovos não-tratados do hospedeiro natural foram verificados por meio de observações do comportamento de parasitismo e o número de ovos em que o parasitóide se desenvolveu com sucesso. Foi verificado que pode ocorrer mortalidade durante o desenvolvimento de ambos os parasitóides estudados, quando parasitando ovos de seus respectivos hospedeiros naturais. No entanto, não foi verificada mortalidade significativa para a fase imatura quando os parasitóides se desenvolveram em ovos do hospedeiro alter- 
nativo. Os possíveis fatores envolvidos na mortalidade dos estágios imaturos e os efeitos da inviabilização dos ovos do hospedeiro alternativo na estimativa da capacidade de parasitismo de Trichogramma em condições de campo também são discutidos.

Palavras-chave: controle biológico, interação hospedeiro parasitóide, mortalidade de imaturos, taxa de parasitismo.

\section{INTRODUCTION}

Egg parasitoids of the genus Trichogramma are among the most commonly used natural enemies in biological control. Because they are easily mass reared, they have been inundatively released in many agroecosystems on more than 32 million hectares/year (Li, 1994). The successful use of these natural enemies has been attributed to a process of species and/or strain selection, that uses behavioral and biological parameters in the selective process, and the use of quality control in the system of production (Bigler, 1994; Hassan, 1994). The parasitization capacity of Trichogramma is one of the most common biological parameters used to compare the effectiveness among populations of this parasitoid and determine the quality of strains (Bigler, 1994; Dutton et al., 1996). It has also been used as tool for selecting factitious hosts for the mass production of these parasitoids, and has been regarded as the most important trait in selecting Trichogramma species and/or strains for release (Dutton et al., 1996; Gomes \& Parra, 1998). Parasitoid searching capacity, host preference and dispersion are other traits that have been also evaluated as criteria for strain selection (Hassan, 1994), but these methods require more elaborate procedures.

Laboratory assessment of Trichogramma parasitism is usually done by incubating the previously parasitized host egg until its chorion turns black, indicating the successful development of the parasitoid to the prepupal stage. However, this method may underestimate the actual parasitization capacity since mortality during the early stages of Trichogramma development is not measured. Nevertheless, this method is most convenient and is commonly employed to measure host mortality caused by Trichogramma species and many other parasitoids and diseases. Many authors have indicated that this method does not provide the same accuracy as the dissection method in estimating mortality caused by parasitoids (Clancy \& Pierce, 1966; Day \& Saunders, 1990; Day, 1994). This is particularly true for larval parasitoids since some of them inject factors along with the egg that ultimately results in host death regardless of the survival of the parasitoid progeny (Vinson \& Iwantsch, 1980a). Further host and parasitoid mortality may greatly increase in superparasitized hosts (Vinson \& Sroka, 1978) and the stress caused by the development of a single parasitoid may prematurely kill the host (Day, 1994).

The present report aimed to verify if there was any mortality during the early stages of development of Trichogramma galloi Zucchi and Trichogramma pretiosum Riley (Hymenoptera, Trichogrammatidae) in two distinct situations. First, we examined parasitoid larval fate when they were reared on UV-killed eggs of the factitious host Anagasta kuehniella (Zeller) (Lepidoptera, Pyralidae) under laboratory conditions.

Secondly, we determined developmental mortality when parasitoid larvae were developing on live eggs of their natural hosts, Diatraea saccharalis (Fabr.) (Lepidoptera, Crambidae) in the case of T. galloi and Heliothis virescens Fabr. (Lepidoptera, Noctuidae) in the case of $T$. pretiosum.

\section{MATERIAL AND METHODS}

\section{Rearing parasitoids and hosts}

Stock cultures of $T$. galloi and T. pretiosum were reared on UV-treated eggs of the factitious host, A. kuehniella, at controlled conditions (temperature $=25+1^{\circ} \mathrm{C}$; relative humidity $=60+$ $10 \% \mathrm{RH}$; photophase $=14$ h.) (Stein \& Parra, 1987). The factitious host was produced on an artificial diet based of wheat flour and yeast (Parra et al., 1989). Eggs of the natural hosts, $D$. saccharalis and $H$. virescens, were obtained from colonies reared on artificial diets and kept under laboratory conditions (Parra \& Mihsfeldt, 1992). 


\section{Assessing early stage mortality on $U V$-killed eggs}

A. kuehniella eggs were UV-treated and glued on a moistened plastic strip, and offered to parasitoid females in a proportion of 1 female to 10 host eggs for $24 \mathrm{~h}$ (this was done to reduce superparasitism). After exposure to the females, 50 host eggs were sampled and stained with toluidine blue to determine the number of parasitoid eggs/host egg (actual level of parasitism). For this procedure, 250 host eggs were also transferred to incubators at five temperatures $(20,22,25,30$, and $\left.32^{\circ} \mathrm{C}\right)(50 \mathrm{eggs} /$ temperature $)$ in which the level of parasitism was determined by the standard rearing method, i.e., determining whether an egg was parasitized by observing if the chorion of the egg has turned black. As A. kuehniella eggs may support the development of a very limited number of parasitoids (maximum 2), all sampled eggs were incubated individually in small glass vials $(3.0 \mathrm{~cm} x$ $0.7 \mathrm{~cm}$ ) to determine the number of adults that emerged/parasitized host egg. We hypothesized that the standard method would accurately measure the parasitization capacity of Trichogramma species studied if the number of emerged adults/ host egg does not differ from the actual number of parasitoid eggs laid/host egg, determined by using a staining procedure.

The staining procedure consisted of fixing the parasitized host egg in Carnoy's solution (chloroform : ethanol : acetic acid, in a proportion of 6:3:1) for at least $30 \mathrm{~min}$. After fixation the material was stained with a saturated solution of toluidine blue in $80 \%$ ethanol for $45 \mathrm{~min}$. Afterward, the material was immersed for a few minutes in $80 \%$ ethanol to which some droplets of acetic acid were added to stop the staining process. The material was dehydrated through $80 \%$ ethanol ( 2 baths $-15 \mathrm{~min}$ ), 95\% ethanol ( 2 baths $10 \mathrm{~min}$ ), absolute ethanol ( 2 baths $-10 \mathrm{~min}$ ), with final dehydration in toluene ( 2 baths $-10 \mathrm{~min}$ ) (Pizzol, 1978). The stained parasitized eggs were mounted in Canada balsam on microscope slides. The number of parasitoid eggs/host egg was observed under light microscopy, and was compared to the number of adults that emerged from the parasitized eggs that were reared at different temperatures. When mortality occurred after the prepupal stage (host chorion had already blackened), the host egg was dissected to assess the number of parasitoids that developed in that egg. Stained host eggs identified as superparasitized, i.e., they contained more than 2 parasitoid eggs in the same egg, were recorded separately since the development of the parasitoids will not reach the prepupal stage and the host eggs will not turn black (Saakyan-Baranova, 1990).

\section{Assessing early stage mortality on live natural host eggs}

Another set of experiments was developed to verify the early stage mortality in a more natural situation by rearing both parasitoids on UVuntreated live natural hosts. For this purpose, newly-emerged females of $T$. galloi and $T$. pretiosum were isolated in small glass vials $(3.0 \mathrm{x}$ $0.5 \mathrm{~cm}$ ), and offered 5 one-day-old eggs of $D$. saccharalis and $H$. virescens, respectively. This was repeated 14 times with a total of 70 eggs being observed/host. Each female was observed during 30 minutes under a WILD M10 stereomicroscopic connected to a CCD video-camera. These observations allowed us to determine all the behavioral steps during parasitism by each Trichogramma which can provide information as to whether a host egg was parasitized and the number of eggs oviposited (Klomp et al., 1980; Suzuki et al., 1984). This is more time consuming than the staining method, but gives the expected parasitization without killing the host. Mortality during the early developmental stages of both parasitoid species was estimated by comparing the expected parasitization with the number of those eggs in which the parasitoid reached the prepupal stage (observed parasitization). Since Trichogramma females may lay more than one egg in a single host during the same ovipositor insertion, blackened eggs were dissected to observe the number of developed pupae in each parasitized egg.

\section{RESULTS AND DISCUSSION}

The parasitization rates determined using UVtreated eggs of the factitious host A. kuehniella by using the staining and standard rearing methods were near $100 \%$ (Table 1). The number of parasitoids that emerged from parasitized host eggs after rearing them in five temperatures was similar to the number of the parasitoid eggs laid in the host egg as determined by the staining procedure (Table 1). 
TABLE 1

Mean number $(\overline{\mathbf{x}} \pm \mathrm{se})$ of parasitoid eggs oviposited (determined by staining) and mean number that emerged as adults/host egg of the factitious host when parasitized by $T$. galloi and $T$. pretiosum and held in different temperatures (relative humidity $=60 \pm 10 \%$; photophase $=14 \mathrm{~h}$ ).

\begin{tabular}{|c|c|c|}
\hline & \multicolumn{2}{|c|}{$(\overline{\mathbf{a}} \pm \mathrm{se})^{1}$} \\
\hline & T. galloi & T. pretiosum \\
\hline Number of eggs oviposited per host & $0.98+0.09 \mathrm{a}$ & $0.92+0.09 \mathrm{a}$ \\
\hline \multicolumn{3}{|l|}{ Number of adults emerging per host at: } \\
\hline $20^{\circ} \mathrm{C}$ & $0.96+0.04 \mathrm{a}$ & $0.83+0.08 \mathrm{a}$ \\
\hline $22^{\circ} \mathrm{C}$ & $1.01 \pm 0.06 \mathrm{a}$ & $0.96 \pm 0.05 \mathrm{a}$ \\
\hline $25^{\circ} \mathrm{C}$ & $0.98+0.04 \mathrm{a}$ & $0.84+0.08 \mathrm{a}$ \\
\hline $30^{\circ} \mathrm{C}$ & $1.03+0.05 \mathrm{a}$ & $0.90+0.07 \mathrm{a}$ \\
\hline $32^{\circ} \mathrm{C}$ & $1.03 \pm 0.07 \mathrm{a}$ & $1.00 \pm 0.05 \mathrm{a}$ \\
\hline
\end{tabular}

1. Means followed by the same letter within columns are not significantly different at 0.05 level (Tukey's Test).

These data indicate that there was no mortality during the egg-larval development of $T$. galloi or T. pretiosum when parasitizing UV-treated eggs of A. kuehniella. Further, the survivorship of the early stages of both parasitoids was not affected by the range of temperature studied (Table 1 ). Because a low ratio of parasitoids to host eggs was used we only found $0.02 \%-0.04 \%$ of the mortality was caused by superparasitization of the host eggs by $T$. galloi and $T$. pretiosum. This mortality was removed from the calculations. These results show that the standard (rearing) method employed to determine the parasitization capacity of Trichogramma in laboratory conditions is appropriate to indicate the actual parasitoid parasitization capacity if the ratio of parasitoid to host is low. However, the same may not be true when Trichogramma minutum Riley (Hym., Trichogrammatidae) are reared on a high parasitoid to host ratio (1 to 1.2), since high immature mortality was found for parasitoids developing on $A$. kuehniella Gamma-irradiated eggs (Corrigan et al., 1995). However, there are several differences in the methods used by Corrigan et al. (1995) and this study. One is the use of Gamma-irradiated eggs by Corrigan et al. (1995) which may be harsher on the contents of the eggs than ultraviolet irradiation used in this study. Second is the high parasitoid to host egg ratio that likely produced a much higher level of superparasitism that did not occur in this study. In larval parasitoids high levels of superparasitism are known to cause mortality (Vinson \& Sroka, 1978) and may occur even in a gregarious species if the number of eggs exceed the carrying capacity of the host as a resource.

In the natural host study we observed only one egg laid during each oviposition attempt and found only one pupa developing in each parasitized egg. We thus assumed that we had the same number of parasitoids developing on parasitized eggs where we found egg mortality, since the time spent by parasitoid females during the oviposition on each host was the same.

Based on these results, the development of both parasitoids on live natural hosts that were not UV treated indicated the occurrence of significant mortality during the early developmental stages of the parasitoids, since the percentage of parasitized eggs determined after rearing the host egg was lower than expected (based on the number of eggs determined by observing the parasitization behavior). In contrast to the UV-irradiated eggs there were significant differences between the expected (based on oviposition observations) and observed (based on host chorion darkening) ( $T$. galloi: $\mathrm{t}=3.391 ; \mathrm{df}=69 ;$ two-tail $P$ value $=$ $0.0012 ;$ T. pretiosum: $\mathrm{t}=3.253 ; \mathrm{df}=69 ;$ two-tail $P$ value $=0.0018$, using a paired t test, $P<0.05)$ (Fig. 1). These results suggest that the utilization of live natural hosts may underestimate the parasitization capacity of $T$. galloi and T. pretiosum when compared to UV-treated eggs of the factitious host, at least for these two species. 


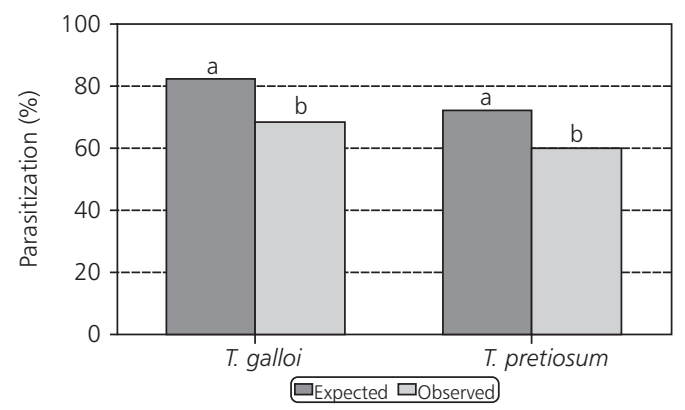

Fig. 1 - Comparison between the expected (initial) and observed (final) parasitization of untreated eggs of D. saccharalis and $H$. virescens by T. galloi and T. pretiosum. respectively. Expected parasitization was assessed by recording female's parasitism behavior and observed parasitization by counting the number of host eggs that turned black (temperature: $24 \pm 1^{\circ} \mathrm{C}$ and $\mathrm{RH}$ : $60 \pm 10 \%$ ). Different letters indicate statistical significance (paired t test. $P<0.05 \%$ ).

These results also indicate the UV-treatment, which is commonly employed for the production of Trichogramma species on the Mediterranean flour moth eggs, enhances the survival of the early stages of these natural enemies by limiting or avoiding unknown mortality factor(s) observed when using live natural hosts. The mortality of the early stages observed on the live habitual hosts may explain the problems found in the mass rearing of $T$. galloi using live eggs of another factitious host, Sitotroga cerealella (Parra, 1997).

Mortality during the immature development of Trichogramma may also be related to the degree of adaptation between the parasitoid strain and the host. Gomes \& Parra (1998) found a very variable parasitoid mortality (although evaluated after prepupal development) among many strains of $T$. pretiosum and T. galloi when developing on the most commonly used factitious hosts, A. kuehniella, Corcyra cephalonica (Stainton) (Lepidoptera, Pyralidae) and S. cerealella (Oliv.) (Lepidoptera, Gelechiidae).

Even though eggs do not present any cellular defenses (Vinson, 1994, and references therein), they may have evolved other ways of limiting parasitoid attack. One of this is through a fast rate of development (Vinson, 1994). Strand (1986) and Strand et al. (1986) reported a significant negative correlation between the developmental time of a host and the percentage of the embryonic development that was susceptible to parasitism. As for many egg and pupal idiobiont parasitoids there is a restricted period for female oviposition. This happens because the host will turn unsuitable for larval development after a defined stage of development since the nutritional quality of these host stages changes during embryogenesis or pupal development (Mackauer \& Sequeira, 1993; Vinson, 1994; Godfray, 1994). Pak et al. (1986) reported that many Trichogramma species showed a specific behavior for a selected host-age. For example, $T$. pretiosum and T. minutum may successfully parasitize their hosts close to eclosion (Marston \& Ertle, 1969; Strand, 1986), while for T. evanescens the host egg turned progressively unsuitable during the last 12-24 h of development and were not suitable at the head capsule stage (Lewis \& Redlinger, 1969).

However, the results of this study suggest that habitual host eggs may have some means of defense against egg parasitoids. This possibility certainly deserves further consideration. Other mortality factors may also be involved when Trichogramma are subject to development in natural hosts (Vinson \& Iwantsch, 1980b). When searching for host eggs in the field, parasitoid females may accept an older host or a host that may be inappropriate for the parasitoid's development due to various conditions that have to be clarified. For example, UV radiation would eliminate potential pathogens which are often not compatible with parasitoid development (Vinson, 1990). The development of the host embryo may be stopped by the wounds caused by the insertion of the ovipositor, injection of a poison or other factors, including adult feeding (Hawlitzky \& Boulay, 1982; Strand, 1986; Driesche et al., 1987). Further research will be necessary to understand immature mortality that occurs during 
the development of the parasitoid and may help modeling host-parasitoid interactions in the field, since many ages of the host eggs are encountered under such conditions.

\section{REFERENCES}

BIGLER, F., 1994, Quality control in Trichogramma production. In: E. Wajnberg \& S. A. Hassan (eds.), Biological Control with Egg Parasitoids. CAB International, Wallingford, pp. 93-111.

CLANCY, D. W. \& PIERCE, H. D., 1966, Some natural enemies of some lygus bugs. J. Econ. Entomol., 59: 853858.

CORRIGAN, J. E., LAING, J. E. \& ZUBRICKY, J. S., 1995, Effects of parasitoid to host ratio and time of day of parasitism on development and emergence of Trichogramma minutum (Hymenoptera: Trichogrammatidae) parasitizing eggs of Ephestia kuehniella (Lepidoptera: Pyralidae). An. Entomol. Soc. Am., 88: 773-780.

DAY, W. H., 1994, Estimating mortality caused by parasites and diseases of insects: comparisons of the dissection and rearing methods. Environ. Entomol., 23: 543-550.

DAY, W. H. \& SAUNDERS, L. B., 1990, Abundance of the garden fleahopper (Hemiptera: Miridae) on alfafa and parasitism by Leiophron uniformis (Gahan) (Hymenoptera: Braconidae). J. Econ. Entomol., 83: 101-106.

DUTTON, A., CERUTTI, F. \& BIGLER, F., 1996, Quality and environmental factors affecting Trichogramma brassicae efficiency under field conditions. Entomol. Exp. Appl., 81: 71-79.

DRIESCHE, R. G. VAN, BELLOTTI, A., HERRERA, C. J. \& CASTELLO, J. A., 1987, Host feeding and ovipositor insertion as sources of mortality in the mealybug Phenacoccus herreni caused by two encyrtids, Epidinocarsis diversicornis and Acerophagus coccois. Entomol. Exp. Appl., 44: 97-100.

GODFRAY, H. C. J., 1994, Parasitoids: behavioral and evolutionary ecology, Princeton University Press, Princeton.

GOMES, S. M. \& PARRA, J. R. P., 1998, The parasitization as a tool for factitious host selection for Trichogramma galloi Zucchi and T. pretiosum Riley. Mitt. Biol. Bundesanst. Land-Forst., 356 (in press).

HASSAN, S. A., 1994, Strategies to select Trichogramma species for use in biological control. In: E. Wajnberg \& S. A. Hassan (eds.), Biological Control with Egg Parasitoids. CAB International, Wallingford, pp. 55-72.

HAWLITZKY, N. \& BOULAY, C., 1982, Régimes alimentaires et développement chez Trichogramma maidis Pintureau et Voegelé (Hym. Trichogrammatidae) dans l'oeuf d'Anagasta kuehniella Zeller (Lep. Pyralidae). Coll. INRA, 9: 101-106.

KLOMP, K., TEERINK, B. J. \& MA, W. C., 1980, Discrimination between parasitized and unparasitized hosts in the egg parasite Trichogramma embryophagum [Hym.: Trichogrammatidae]: a matter of learning and forgetting. Neth. J. Zool., 30: 254-277.
LEWIS, W. J. \& REDLINGER, L. M., 1969, Suitability of eggs of the almond moth, Cadra cautella, of various ages for parasitism by Trichogramma evanescens. An. Entomol. Soc. Am., 62: 1482-1484.

LI, L. Y., 1994, Worldwide use of Trichogramma for biological control on different crops: a survey. In: E. Wajnberg \& S. A. Hassan (eds.), Biological Control with Egg Parasitoids. CAB International, Wallingford, pp. 37-54.

MACKAUER, M. \& SEQUEIRA, R., 1993, Patterns of development in insect parasites. In: N. E. Beckage, S. N. Thompson \& B. A. Federici (eds.), Parasites and Pathogens of Insects, vol. 1: Parasites. Academic Press, Inc., New York, pp. 1-23.

MARSTON, N. N. \& ERTLE, L. R., 1969, Host age and parasitism by Trichogramma minutum (Hymenoptera: Trichogrammatidae). An. Entomol. Soc. Am., 62: 14761482.

PAK, G. A., BUIS, H. C. E. M., HECK, I. C. C. \& HERMANS, M. L. G., 1986, Behavioral variations among strains of Trichogramma spp.: host-age selection. Entomol. Exp. Appl., 40: 247-258.

PARRA, J. R. P., 1997, Técnicas de criação de Anagasta kuehniella, hospedeiro alternativo para a produção de Trichogramma. In: J. R. P. Parra \& R. A. Zucchi (eds.), Trichogramma e o Controle Biológico Aplicado. FEALQ, Piracicaba, pp. 121-150.

PARRA, J. R. P. \& MIHSFELDT, L. H., 1992, Comparison of artificial diets for rearing the sugarcane borer. In: $\mathrm{T}$. E. Anderson \& N. C. Leppla (eds.), Advances in Insect Rearing for Research and Pest Management. West View, New York, pp. 195-209.

PARRA, J. R. P., LOPES, J. R. S., SERRA, H. J. P. \& SALES JR., O., 1989, Metodologia de criação de Anagasta kuehniella (Zeller, 1879) para produção massal de Trichogramma spp. An. Soc. Entomol. Brasil., 18: $403-$ 405.

PIZZOL, J., 1978. La diapause chez Trichogramma evanescens West. (Hymenoptera, Trichogrammatidae) écotype moldave parasite oophage de la pyrale du maïs. Diplôme Ecole Pratique Hautes Etudes, Montpellier, $75 \mathrm{p}$.

SAAKYAN-BARANOVA, A. A., 1990, Morphological study of preimaginal stages of six species of the genus Trichogramma Westwood (Hymenoptera, Trichogrammatidae). Entomol. Oboz., 69: 257-263.

STEIN, C. P. \& PARRA, J. R. P., 1987, Uso da radiação ultra-violeta para inviabilizar ovos de Anagasta kuehniella (Zeller, 1879) visando estudos com Trichogramma. An. Soc. Entomol. Brasil., 16: 229-233.

STRAND, M. R., 1986, The physiological interactions of parasitoids with their hosts and their influence on reproductive strategies. In: J. K. Waage \& D. Greathead (eds.), Insect Parasitoids. Academic Press, London, pp. 97-136.

STRAND, M. R., MEOLA, S. M. \& VINSON, S. B., 1986 , Correlating pathological symptoms in Heliothis virescens eggs with development of the parasitoid Telenomus heliothidis. J. Insect Physiol., 32: 389-402. 
SUZUKI, Y., TSUJI, H. \& SASAKAWA, M., 1984, Sex allocation and effects of superparasitism on secondary sex ratios in the gregarious parasitoid, Trichogramma chilonis (Hymenoptera: Trichogrammatidae). Animal Behaviour, 32: $478-484$

VINSON, S. B., 1990, Potential impact of microbial insecticides on beneficial arthropods in the terrestrial environment. In: Laird, M., L. A. Lacey \& E. W. Davidson (eds.), Safety of Microbial Insecticides. CRC Press, Inc., Boca Raton, pp. 44-64.

VINSON, S. B., 1994, Physiological interactions between egg parasitoids and their hosts. In: E. Wajnberg \& S. A. Hassan (eds.), Biological Control with Egg Parasitoids. CAB International, Wallingford, pp. 201-217.
VINSON, S. B. \& SROKA, P., 1978, Effects of superparasitism by a solitary endoparasitoid on the host, parasitoid and field samplings. Southwest. Entomol., 3: 299303.

VINSON, S. B. \& IWANTSCH, G. F., 1980a, Host regulation by insect parasitoids. Q. Rev. Biol., 55: 143-165.

VINSON, S. B. \& IWANTSCH, G. F., 1980b, Host suitability for insect parasitoids. Ann. Rev. Entomol., 25: 397-419. 